\title{
ANALISIS MOBILE LEARNING DENGAN LAYANAN VIDEO BERBASIS ANDROID
}

\author{
Denny Wijanarko ${ }^{1)}$ \\ 1) Teknik Komputer Politeknik Negeri Jember \\ Jl. Mastrip PO. Box 164, Jember 68101, Jawa Timur \\ Email : dennywijanarko@gmail.com
}

\begin{abstract}
Dengan semakin berkembangnya Teknologi Informasi dan Komunikasi, perkembangan dunia pendidikan juga ikut berkembang. Dimana pembelajaran sekarang tidak harus langsung di kelas, tapi dapat dilakukan dimana saja dengan menggunakan perangkat berupa internet, wifi, mobile device ataupun videoconferencing. Karena metode pembelajarannya yang memanfaatkan elektronika maka biasa disebut dengan e-learning (electronic learning). Dalam perkembangannya e-learning akan berevolusi menjadi mobile learning. Dan perkembangan terbaru dalam teknologi mobile semakin memungkinkan untuk mendukung pembelajaran bergerak dan memanfaatkan situasi belajar yang spontan dan efisien serta dapat dilakukan pada anywhere dan anytime

Dengan permasalahan tersebut dapat dilakukan pengembangan mobile learning yang berbasis android dengan memanfaatkan layanan video, karena sistem pembelajarannya lebih bervariatif dan efisien.

Oleh karena itu perlu dilakukan analisa mengenai performansi dari jaringan mobile learning agar nantinya dapat digunakan sebagai acuan dalam membuat suatu sistem mobile learning yang baik. Pengujian mobile learning ini akan dilakukan pada jaringan wireless dengan cara melakukan download atau akses pada mobile learning object. Pengujian dilakukan dengan memvariasikan nilai bandwidth dan ukuran dari mobile learning object yang akan diukur dengan menggunakan Wireshark.
\end{abstract}

Kata Kunci: Mobile Learning, Mobile learning untuk layanan video, Mobile learning pada jaringan wireless, Mobile Learning berbasis android.

\section{PENDAHULUAN}

Perkembangan teknologi telah menciptakan pengembangan terobosan-terobosan dalam pembelajaran. Di tengah perkembangan ini learner (pembelajar) bersinggungan dengan perangkat-perangkat teknologi komunikasi bergerak dan teknologi internet telah menjadi gelombang kecenderungan baru yang memungkinkan pembelajaran secara mobile atau lebih dikenal sebagai mobile learning (m-learning). Kombinasi teknologi telekomunikasi dan internet memungkinkan pengembangan sistem m-learning yang pada sisi klien memanfaatkan divais begerak, berinteraksi dengan sisi server, yaitu web server (Riyanto. B, 2006).

Akses ke layanan Internet tidak lagi terbatas pada komputer dan laptop, sekarang internet dapat diakses dari perangkat mobile ketika jaringan tersedia. Salah satu layanan yang dapat diakses dari perangkat mobile yang disediakan oleh LMS (Learning Management Sistem). LMS adalah aplikasi e-learning berbasis web yang digunakan dalam oleh lembaga pendidikan dan perusahaan.

Evolusi dari platform pendidikan berbasis web berjalan menuju skenario mobile. Pengajar dan pelajar dapat mengakses konten pembelajaran secara mobile menggunakan web untuk sistem pembelajarannya dengan skenario ubiquitous (dimana-mana). Hal ini menyebabkan adanya aplikasi belajar yang baru dengan mendapatkan keuntungan berdasarkan kondisi yang unik mobilitas dan lokasi perangkat mobile. Namun aplikasi ini harus terintegrasi antara web server, perangkat yang bergerak serta connectivitas (jaringan seluler dan wireless). Selain itu juga banyak terdapat aspekaspek pendukung dalam mendukung ketersediaan mobile learning. Web server, Programming Language (PHP), menggunakan database SQL Lite, koneksi jaringan, dan yang terutama dalam penelitian ini, dari sisi pengguna menggunakan mobile device yang berplatform dan ber-Operasi Sistem Android. Didalam perangkat tersebut nantinya akan ditanamkan aplikasi app.apk yang dapat bersinkronisasi dengan web server lokal maupun server domain yang berbayar.

Pada penelitian ini akan difokuskan pada aplikasi pembelajaran melalui layanan video dan melakukan analisa performansi dari mobile learning yang berbasiskan android. Hal ini dikarenakan perkembangan teknologi dan aktifitas yang tinggi dari seorang pengajar maupun siswa sehingga diperlukan solusi yang bagus dalam menyelesaikan permasalahan ini. Salah satu solusi yang ditawarkan adalah dengan menggunakan mobile learning. Salah satu strategi yang paling penting untuk mobile learning berfokus pada pembelajaran menggunakan layanan video yang dapat dilaksanakan dimana saja, komunikasi dalam dialog, dan konektivitas untuk memenuhi aspek-aspek komunitas dan platform 
belajar. sehingga kelas virtual dapat dibangun dengan baik pada keadaan ini.

Kendala pengembangan aplikasi m-learning adalah keterbatasan sumber daya dan keragaman platform sehingga perlu rancangan yang mampu mengatasi kendala ini sehingga dapat dikembangkan aplikasi yang memiliki kompatibilitas dan interoperabilitas tinggi. Marc Alier Forment telah mengembangkan mobile learning pada Universitat Politècnica de Catalunya di Barcelona Spanyol, tetapi pada pengembangannya menggunakan moodbile yang di bangun dalam bahasa spanyol yang hanya bisa di akses dengan menggunakan android, serta memerlukan spesifikasi device yang tinggi (Alier, 2009), sehingga untuk diterapkan di Indoesia akan mengalami sedikit hambatan.

\section{METODOLOGI PENELITIAN}

Langkah-langkah penelitian dalam sistem ini meliputi beberapa tahap. Tahapan tersebut ditunjukkan dengan flowchart pada Gambar 1. Penjelasan lebih rinci digambarkan pada diagram alir tersebut adalah sebagai berikut :

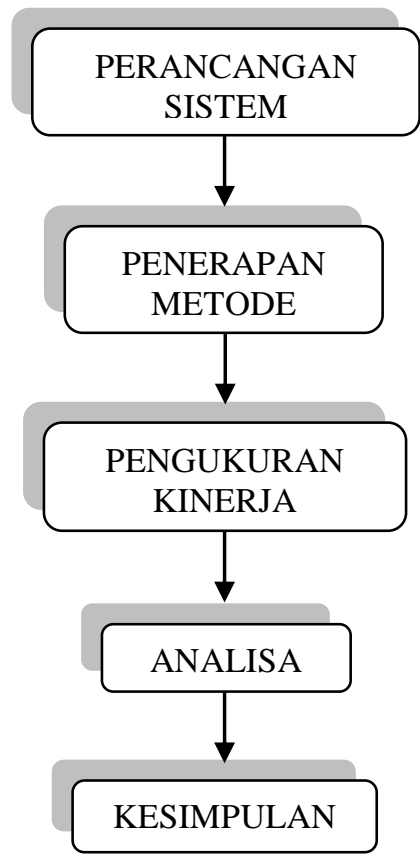

Gambar 1. Langkah-langkah Penelitian

Penjelasan:

1. Pada tahap ini akan membahas perancangan sistem yang akan di implementasikan dan kebutuhan perangkat yang dibutuhkan dalam melakukan implementasianya. Perancangan yang dilakukan pada jaringan wireless.

2. Implementasi sistem mobile learning, akan dibahas tentang implementasi jaringan dengan menggunakan jaringan wireless, pada server dan user
3. Pengambilan data dapat dilakukan dengan menjalankan mobile learning pada user untuk mendapatkan mobile learning object yang telah dibuat sebelumnya. Untuk itu pengukuran data akan diukur ketika proses kedua transfer data di atas berlangsung. Adapun paket data yang di-transfer merupakan data mobile learning object dengan berbagai ukuran yang terdapat pada server. Kemudian dari hasil uji coba tersebut diambil data dengan bantuan software Wireshark.

4. Pengujian QoS pada aplikasi sistem mobile learning dapat diamati dengan menggunakan program Wireshark. Wireshark mampu membaca paket-paket data yang lewat pada jaringan dan menganalisanya. Beberapa protokol yang didukung Wireshark antara lain TCP, UDP, RTP, SIP, dan lain-lain. Akan tetapi data pada proses ini adalah TCP. Beberapa parameter yang di-capture melalui Wireshark untuk pengujian QoS.

a. Throughput

Throughput adalah besarnya keberhasilan rate yang diterima pada pengiriman proses data. Biasanya throughput selalu dikaitkan dengan bandwidth. Untuk men-capture nilai throughput dapat dilakukan dengan melihat nilai bit per second (bps) dari B ke A. B adalah server dan A adalah client pada hasil Conversation di Wireshark.

b. Waktu

Waktu transfer merupakan waktu yang dibutuhkan untuk menyelesaikan proses download/akses di antara server MLE dengan client. Untuk melihat waktu transfer kita dapat melihatnya dari nilai duration. Duration adalah lama waktu yang dibutuhkan untuk mengirimkan data yang terjadi hanya pada alamat-alamat tertentu. Nilai ini juga dapat dilihat pada Conversation di Wireshark

Pengujian ini dilakukan dengan memvariasikan ukuran dari Mobile Learning Object (MLO) yang berbeda-beda yaitu $9 \mathrm{Mb}$ dan $40 \mathrm{Mb}$ serta bandwidth $64 \mathrm{kbps}$ dan $512 \mathrm{kbps}$. Pengukuran pada bagian ini dilakukan menggunakan server dengan user melalui jaringan wireless dan kemudian diamati throughput dan durasi waktunya

5. Penarikan kesimpulan dari hasil analisis untuk menjawab rumusan permasalahan serta rekomendasi untuk penelitian selanjutnya.

\section{HASIL DAN PEMBAHASAN}

Pada uraian ini akan dilakukan pembahasan mengenai implementasi sistem serta menganalisa data tentang performansi kerja jaringan sistem mobile learning. Analisa dilakukan berdasarkan pengujian terhadap kinerja transfer data antara server dengan device client seperti pengujian dengan mengubah variabel besar ukuran Mobile Learning 
Object (MLO). Beberapa paramater network performance-nya yang ditinjau akan meliputi throughput dan pengukuran waktu.

\section{a. Implementasi Sistem}

Implementasi yang dilakukan pada jaringan wireless ini menggunakan satu buah notebook dan satu device. Notebook difungsikan sebagai virtual access point agar dapat melakukan data-sharing dan mobile devicenya digunakan sebagai client. Setelah semua sudah saling terhubung akan dilakukan analisis parameter yang akan di uji. Implementasi ini dilakukan dengan pengiriman data menggunakan fasilitas jaringan wireless.

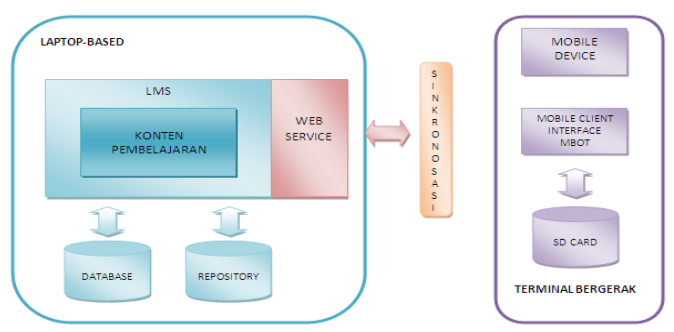

Gambar 2. Implementasi mobile learning

\section{b. Pengujian, Pengukuran dan Analisa Data}

Pengujian performansi mobile learning dilakukan pada jaringan wireless untuk mengetahui performansi dari sistem yang telah dibangun. Pada pengujian ini paramater network performance-nya yang ditinjau akan meliputi throughput dan pengukuran waktu.

Pada pengukuran performansi mobile learning ini akan dilakukan download file yang berupa mobile learning object yang berisi video, dengan memvariasikan ukuran dari mobile learning object.

\section{Pengujian Throughput}

Pengujian throughput diamati dengan melakukan pengukuran throughtput pada sisi client yang terhubung dengan server. Pengukurannya dengan cara melakukan download file video dari server menuju client. Pada bagian ini pengujian sistem mobile learning juga divariasikan pada berbagai kondisi ukuran file video yang berbedabeda yaitu $9 \mathrm{Mb}$ dan $40 \mathrm{Mb}$ serta bandwidth $64 \mathrm{kbps}$ dan 512 kbps. Pengamatan tersebut dilakukan dengan menggunakan bantuan software Wireshark untuk men-capture aliran trafik data atau paket yang diterima.

Berikut Tabel 1 merupakan hasil pengamatan throughput yang telah dilakukan pada mobile learning pada jaringan wireless.
Tabel 1 Data pengukuran Throughput vs Bandwidth

\begin{tabular}{|c|c|c|}
\hline $\begin{array}{c}\text { Bandwidth } \\
\text { (kbps) }\end{array}$ & \multicolumn{2}{|c|}{ Throughput (bps) } \\
\cline { 2 - 3 } & $9 \mathrm{Mb}$ & $40 \mathrm{Mb}$ \\
\hline 64 & 33384 & 32968 \\
\hline 512 & 160536 & 250574 \\
\hline
\end{tabular}

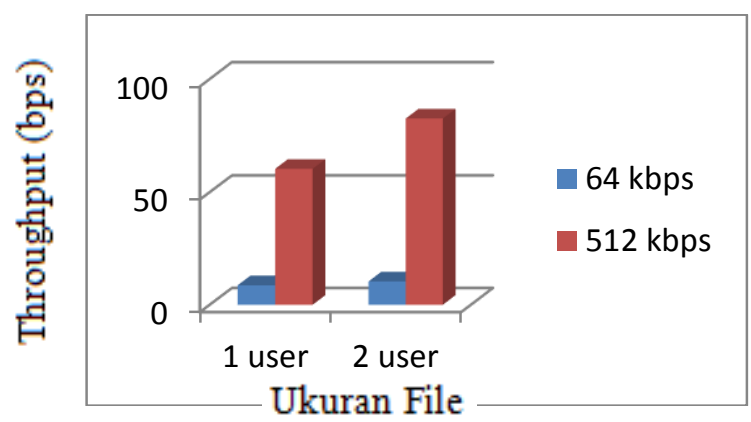

Gambar 3. Pengukuran throughput vs bandwidth pada pengujian mobile learning

Dari Tabel 1 di atas didapatkan hasil pengukuran throughput di jaringan wireless dapat diilustrasikan dalam gambar 3 grafik perbandingan nilai throughput. Berdasarkan data di atas nilai throughput yang paling kecil didapatkan pada bandwidth $64 \mathrm{Kbps}$ dengan ukuran file $40 \mathrm{Mb}$ dengan nilai sebesar 32968 bps sedangkan nilai paling besar adalah pada saat pengujian dengan menggunakan bandwidth $512 \mathrm{Kbps}$ dengan ukuran file $40 \mathrm{Mb}$ yaitu sebesar 250574 bps. Hal ini dapat disimpulkan bahwa semakin besar nilai bandwidth, maka nilai throughput nya akan semakin besar dikarenakan lebar bandwidth akan mempengaruhi nilai dari throughput. Semakin besar ukuran file, maka nilai throughputnya akan semakin besar juga hal ini disebabkan semakin besar ukuran file, maka packet yang dikirimkan akan semakin banyak.

\section{Pengamatan Waktu}

Pengukuran waktu mobile learning pada penelitian ini dilakukan untuk mengamati seberapa lama proses mobile learning ini selesai. Pengamatan dilakukan dengan cara memvariasikan ukuran file video yang disediakan yaitu $9 \mathrm{Mb}$ dan $40 \mathrm{Mb}$ serta bandwidth $64 \mathrm{kbps}$ dan $512 \mathrm{kbps}$. Pada Tabel 2 didapatkan hasil pengamatan waktu proses mobile learning yang dilakukan terhadap sebagaimana berikut di bawah ini.

\section{Tabel 2 Data pengukuran Waktu vs Bandwidth}

\begin{tabular}{|c|c|c|}
\hline \multirow{2}{*}{$\begin{array}{c}\text { Bandwidth } \\
\text { (kbps) }\end{array}$} & \multicolumn{2}{|c|}{ Waktu (detik) } \\
\cline { 2 - 3 } & $9 \mathrm{Mb}$ & $40 \mathrm{Mb}$ \\
\hline 64 & 8,6829 & 60,3401 \\
\hline 512 & 4,9568 & 31,5734 \\
\hline
\end{tabular}




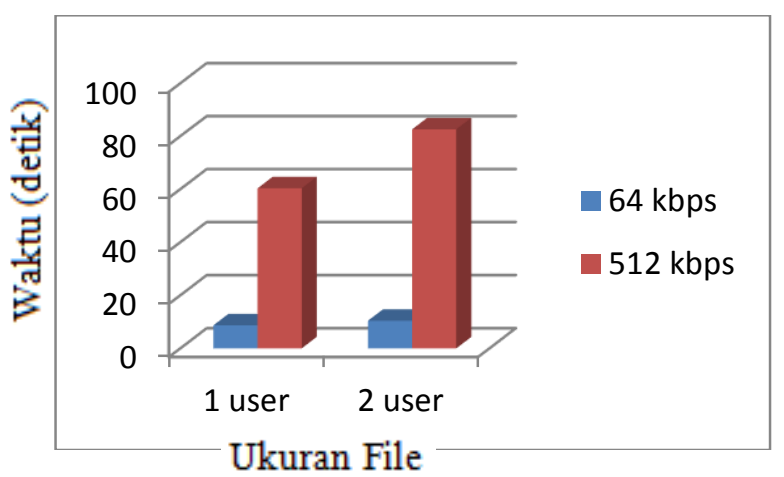

Gambar 4. Pengukuran waktu vs bandwidth pada pengujian mobile learning

Berdasarkan Gambar 4 didapat nilai waktu yang paling kecil didapatkan pada bandwidth $512 \mathrm{Kbps}$ dengan ukuran file $9 \mathrm{Mb}$ dengan nilai sebesar 4,9568 detik. Hal ini dapat disimpulkan bahwa semakin besar ukuran mobile learning object dan semakin kecil bandwidth yang diberikan maka waktu yang diperlukan untuk melakukan akses akan semakin lama. Selain dipengaruhi nilai bandwidth, lama loading time juga dipengaruhi oleh throughput. Dimana semakin besar nilai throughputnya, maka nilai dari loading timenya akan semakin kecil. Nilai throughput ini akan mempengaruhi dari loading time, karena throughput merupakan bandwidth aktual.

\section{c. Pengujian Skalabilitas Performansi Jaringan Mobile Learning}

Pengujian skalabilitas ini dimaksudkan untuk mengetahui performansi unjuk kerja jaringan (network performance) dari proses mobile learning terhadap banyaknya client yang melakukan mobile learning secara bersamaan. Pada pengujian skalabilitas ini diawali dengan melakukan pengujian mobile learning terhadap satu client untuk diamati performansinya. Kemudian pengujian akan dilakukan kembali untuk dua client. Pengujian sistem mobile learning juga divariasikan pada berbagai kondisi ukuran file video yang berbedabeda yaitu $9 \mathrm{M}$ dan $40 \mathrm{Mb}$

\section{Pengujian Throughput}

Pengujian throughput diamati dengan melakukan pengukuran throughtput pada sisi client yang terhubung dengan server. Pengukurannya dengan cara melakukan download file video dari server menuju client.

Berikut Tabel 3 merupakan hasil pengamatan throughput yang telah dilakukan pada mobile learning pada jaringan wireless.
Tabel 3 Data pengukuran throughput (multi user)

\begin{tabular}{|c|c|c|}
\hline & \multicolumn{2}{|c|}{ Throughput (bps) } \\
\hline $\begin{array}{c}\text { Ukuran } \\
\text { file (Mb) }\end{array}$ & 1 user & 2 user \\
\hline 9 & 33384 & 26992 \\
\hline 40 & 32968 & 33161 \\
\hline
\end{tabular}

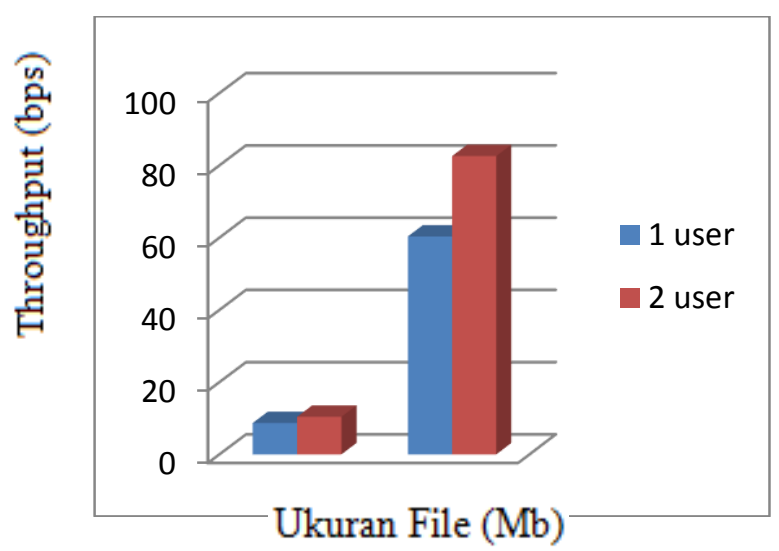

Gambar 5. Pengukuran throughput pada pengujian multi user

Berdasarkan hasil pengamatan nilai throughput yang ada pada Tabel 3, misalnya kita mengambil contoh pada file berukuran $9 \mathrm{Mb}$, didapat nilai throughput terbaik didapatkan pada saat menggunakan 1 user yaitu 33384 bps dan throughput paling rendah pada saat digunakan dua user secara bersamaan melakukan akses mobile learning pada Mobile Learning Object yaitu 26992 bps. Hal ini dikarenakan semakin banyak jumlah user, maka semakin banyak juga packet yang dikirim sehingga mengakibatkan throughputnya akan semakin kecil juga.

\section{Pengamatan Waktu}

Pengukuran waktu pada bagian ini diamati pada sisi client yang telah terhubung dengan server. Adapun pengukuran waktu dapat diamati dengan seberapa lama proses mobile learning ini selesai.

Berikut Tabel 4 hasil pengamatan data waktu yang terjadi selama proses pengiriman data mobile learning object dengan user sebanyak empat user.

Tabel 4 Data pengukuran Waktu (multi user)

\begin{tabular}{|c|c|c|}
\hline & \multicolumn{2}{|c|}{ Waktu (detik) } \\
\hline $\begin{array}{c}\text { Ukuran } \\
\text { file }(\mathrm{Mb})\end{array}$ & 1 user & 2 user \\
\hline 9 & 8,68 & 10,41 \\
\hline 40 & 60,34 & 82,59 \\
\hline
\end{tabular}




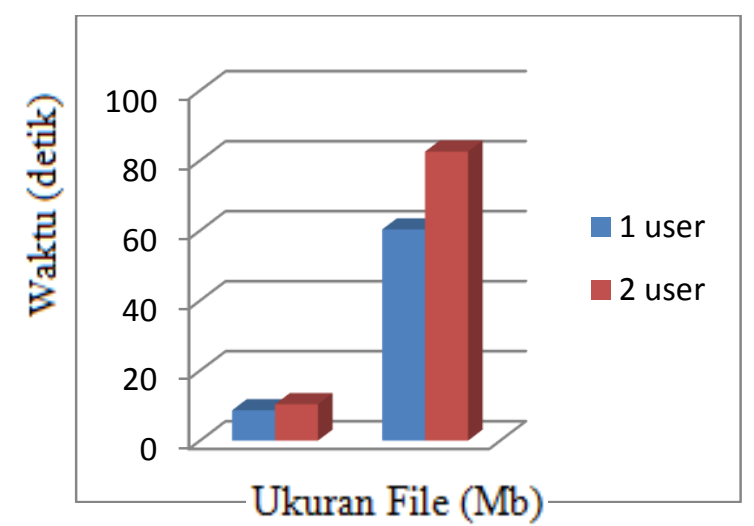

Gambar 6. Pengukuran waktu pada pengujian multi user

Berdasarkan hasil data dari Tabel 4, misalnya kita mengambil contoh pada file berukuran $9 \mathrm{Mb}$, dapat diilustrasikan dalam bentuk grafik perbandingan pada Gambar 6. Pada gambar tersebut dapat diamati bahwa waktu tercepat untuk melakukan proses mobile learning didapatkan pada pengujian skalabilitas menggunakan satu client yaitu 8,68 detik dan paling lama menggunakan dua client secara bersamaan, yaitu 10,41 detik.

Selain dipengaruhi nilai bandwidth, lama loading time juga dipengaruhi oleh throughput. Dimana semakin besar nilai throughputnya, maka nilai dari loading timenya akan semakin kecil. Nilai throughput ini akan mempengaruhi dari loading time, karena throughput merupakan bandwidth aktual.

\section{KESIMPULAN DAN SARAN}

\section{Kesimpulan}

Berdasarkan pembahasan tersebut maka dapat ditarik kesimpulan sebagai berikut:

1. Pada perencanaan mobile learning dapat diaplikasikan dengan mengintegrasikan antara web server dan aplikasi android app.apk

2. Semakin besar nilai bandwidth, maka nilai throughput nya akan semakin besar dikarenakan lebar bandwidth akan mempengaruhi nilai dari throughput. Semakin besar ukuran file, maka nilai throughputnya akan semakin besar juga hal ini disebabkan semakin besar ukuran file, maka packet yang dikirimkan akan semakin banyak.

3. Semakin besar ukuran mobile learning object dan semakin kecil bandwidth yang diberikan maka waktu yang diperlukan untuk melakukan akses akan semakin lama.

4. Semakin banyak jumlah user, maka semakin banyak juga packet yang dikirim sehingga mengakibatkan throughputnya akan semakin kecil juga.

5. Selain dipengaruhi nilai bandwidth, lama loading time juga dipengaruhi oleh throughput. Dimana semakin besar nilai throughputnya, maka nilai dari loading timenya akan semakin kecil. Nilai throughput ini akan mempengaruhi dari loading time, karena throughput merupakan bandwidth aktual.

\section{Saran}

Adapun beberapa saran yang dapat diberikan oleh penulis adalah sebagai berikut :

1. Pada pengujian perlu ditambahkan jumlah client serta melakukan pengujian pada jaringan seluler lainnya.

2. Melakukan pengujian pada client dengan menggunakan operasi sistem selain android

3. Memberikan variasi pada ukuran file video yang lebih banyak

\section{UCAPAN TERIMA KASIH}

Puji syukur kepada Allah S.W.T atas anugerah yang telah dilimpahkan-Nya sehingga penulisan penelitian dengan judul : "ANALISIS MOBILE LEARNING DENGAN LAYANAN VIDEO BERBASIS ANDROID" dapat diselesaikan dengan baik.

Pada kesempatan ini penulis sampaikan terima kasih kepada :

1. Politeknik Negeri Jember

2. Rekan-rekan Staf Pengajar Jurusan Teknologi Informasi Politeknik Negeri Jember.

3. Rekan-rekan yang membantu proses terselesaikannya penelitian ini.

Penulis menyadari bahwa dalam penulisan ini masih jauh dari sempurna, untuk itu demi perbaikan dan penyempurnaannya, maka kritik dan saran sangat diharapkan.

\section{DAFTAR PUSTAKA}

Alier M F. José M. (2009), Moodlbile: Extending Moodle to The Mobile On/Offline Scenario. Proceedingsin The IADIS 2009

Rachel C, T Stephen, S Jude, B Axel. (2006), "Literature Review Into Mobile Learning in The University Context. Queensland": Queensland University of Technology Creative Industries Faculty.

Riyanto. B, (2006), "Perancangan Aplikasi MLearning Berbasis Java". Prosiding Konferensi Nasional Teknologi Informasi \& Komunikasi untuk Indonesia 3-4 Mei 2006. 386-392.

ITU-T P.800, Methods for subjective determination of transmission quality, http:// www. itu.int/itu-t/publications, April 2010 